\title{
Judit Niran Frigyesi, Writing on Water: The Sounds of Jewish Prayer
}

(Budapest: Central European University Press, 2018. ISBN 9789633862 57 5; 269 pp.)

Every so often, one encounters a non-fiction book that cannot be categorized easily. Such books might include Arthur Zajonc's 1993 Catching the Light: The Entwined History of Light and Mind, in which Zajonc explores the phenomenon of vision through the disciplines of history, mythology, physics, theology, fine arts, and philosophy. Another such category-defying book is Michael Lesy's 1973 cult classic Wisconsin Death Trip, a work that frames a collage of news clippings, selections from psychiatric notes, nineteenth- and early twentieth-century American novels and poetry, photography, and repurposed clip art with essays examining the moral, psychological, and emotional breakdown of the small town of Black River Falls, Wisconsin during the great depression of the 1890s through a distinctly Freudian lens.

Both of these books take the position that the human experience cannot, and perhaps should not, be broken into distinct disciplinary categories. Vision, an act that encompasses both the perception of objects and the interpretation of that perception, is more than just a function of physics, or of biology. As Zajonc makes clear in the story with which he opens his book, blind people whose eyes are healed surgically must still be taught to "see," to interpret and understand the patterns of light, dark, and color that their eyes pick up. And, as Lesy observes, an onslaught of tales of death, madness, and despair in a remote mining and logging community in northern Wisconsin cannot be attributed simply to dire economic straits, or disease epidemics, or a strict sense of religion. All of these factors, and many others, must contribute to a social situation that encompasses teenage servant girls setting their employers' houses on fire simply to have some excitement in their lives, as well as old women becoming so terrified of minor skin rashes 
that they douse themselves in fuel and set themselves on fire. These are complex phenomena that can only be comprehended by taking a step back from the constrictions of individual academic disciplines and making an effort to look at a larger picture.

In Writing on Water: The Sounds of Jewish Prayer, Judit Niran Frigyesi joins Lesy and Zajonc in their quest to leave disciplinary boundaries behind and explore a facet of human existence through multiple avenues of inquiry. Writing on Water draws from several different genres and disciplines. Part of it is memoir, part of it is poetry, part of it is photography, part of it is ethnography, and part of it is the transcribed words of people with whom Frigyesi talked and learned about music, prayer, and a community slipping rapidly into the past. Frigyesi prefaces her book by stating that it is "an attempt to grasp the meaning of sound in prayer," and that is certainly the primary thread that runs through the three sections of the book and ties them together. However, like any good quest narrative, the goal proves to be both elusive and not quite what it seems to be at first glance. Frigyesi invites the reader to accompany her on a lengthy, enigmatic journey that goes beyond "sound in prayer" to explore the idea of prayer itself and its role in the precarious, hidden lives of Jewish communities in Hungary in the middle decades of the twentieth century.

The story that Frigyesi tells is one of shifting perspectives, misunderstandings, and meanings that are not quite hidden, but may only be truly accessible through one particular cultural path. Frigyesi never does explain the meaning of sound in prayer to an imagined audience of eager students; rather, she brings her readers with her as she conducts her ethnography, allowing readers to experience for themselves a bit of what it is like to be an ethnomusicologist. In its own way, Writing on Water addresses the problem posed by reflexive works such as Gregory Barz and Timothy Cooley's 1996 Shadows in the Field: New Perspectives for Fieldwork in Ethnomusicology - how do we acknowledge the role and presence of the ethnographer in an ethnographic study? - by inviting the reader to share the role of ethnographer with Frigyesi. She brings the reader with her, first into the mysterious, weighted atmosphere of a secret synagogue in Budapest in 1976, then into her own childhood of suppressed Jewish identity, quietly haunted by the unspoken memory of those who "did not come back," and into her tentative first steps as an ethnographer, charged by a scholar at the Budapest Academy of Music to prove that Hungarian Jewish music, about which this scholar knew very little, had been influenced by ancient Hungarian folk songs. Like a good student, Frigyesi sets out to do the research that will answer this question. She meets people and starts to listen to what they have to say, allowing her reader to listen as well. It is that act of listening that changes the story completely. When she brings the reader along on her early visits to urban synagogues and tiny, secret prayer rooms and into her visits with the elderly men (and one or two women) who pray in them, the reader 
learns along with Frigyesi just how shallow her original assignment really was, as well as the true scale of the mystery that she has uncovered.

For the most part, the people whom Frigyesi comes to know are not interested in the technical dimensions of her scholarship. They treat her initial attempts to transcribe their chanting and learn the chants from recordings and transcriptions as interesting, though ultimately useless, intellectual activities. Slowly and patiently, they teach Frigyesi that she has been asking the wrong questions if she seeks to understand how the melody of Orthodox Hungarian Jewish prayer really works. They impress upon her the idea that chanting the prayers out loud is more important than careful study either of the notated melodies or of the text itself; one interviewee recalls his childhood in Hebrew school memorizing prayer texts until he could chant them fluently, but never being taught what the words meant, despite being taught the Torah with translations and explanations. He tells Frigyesi that " $[\mathrm{t}] \mathrm{he}$ idea was that you should feel the meaning of the text from the sound of the words ... Because the meaning ... the real meaning ... the essence of a prayer ... cannot be translated or explained - it is something inexpressible" (p. 182). This interviewee does not express any particular fondness for this rote-memorization style of teaching, but acknowledges that this is why prayer in the small, private synagogues in Hungary in the latter half of the twentieth century sounded the way it did. The salient aspect of Jewish prayer in this tradition is the kavanah, the whole-hearted focus on the ritual of addressing the Divine. The melodies, the act of chanting, and even the prayer texts themselves serve as stepping-stones to help the worshiper find the proper kavanah. As Frigyesi learns, sound is an inextricable part of prayer, and prayer must sound correctly, but it is ultimately only a small portion of the full meaning of prayer.

Many of Frigyesi's interviewees speak somewhat cryptically of the difficulty in finding enough people to make a minyan, the quorum of (in this tradition) ten adult Jewish men needed to say the entire Sabbath prayer service. They recall the full synagogues of their childhoods and worry about what might happen in the future, as the tiny, primarily elderly congregations of their present day die off. Much like Wisconsin Death Trip, the entire book is suffused with a distinctly elegiac tone, a sense, never directly addressed, that something of terrible importance is not being discussed. In Wisconsin Death Trip, one must understand that the great economic depression of the 1890s is a precipitating factor in the town's problems; in Writing on Water, the unspoken tragedy lurking in the background is the Holocaust, followed by Hungary's period of Communist rule. Frigyesi began her research in an era when the Holocaust was not discussed in Hungary; indeed, few of her interviewees are interested in talking about their time in concentration camps, and more than one ask her to turn her tape recorder off if she wants details. Both her interviews and her family history are haunted by references to those who "did not come back." Although Frigyesi does not spell it out in so many words, it becomes clear as the book progresses that almost all of her interviewees 
are Holocaust survivors, and that the reason that their tiny congregations are so secret and so inward-focused is that the survivor-congregants are traumatized both by the Holocaust and an ongoing official antipathy toward religious services, especially Jewish ones, in post-war Hungary. One man, interviewed in 1979, tells Frigyesi that, should she choose to continue her research, she should plan on leaving the country for her own safety (p. 193). Eventually, she does that; she now lives and works in Israel.

Writing on Water is a book that promises great rewards. However, it must be approached on its own terms. This is not a book to be mined for clearly expressed tidbits of factual information, or even carefully constructed analysis of a social situation or art form. The lack of an index reinforces the idea that this book is not primarily meant to be a source for diligent scholarly research. Rather, it is a book about experience, about using the physical phenomenon of musical sound and the act of chanting to form an emotional and spiritual connection with something larger than oneself. It is as much about the setting, the history, the memories both detailed and unspoken, the fragmented echo of a murdered and suppressed way of life, as it is about musical aspects of Hungarian Jewish prayer chant. It is a book that blends poetry and evocative black-and-white photographs with accounts of ethnographic encounters, and it should be treated like the multi-faceted sensory experience that it describes. The rewards that Writing on Water has to offer may come more easily to the reader who allows him- or herself to sit back, relax, and sink into the book's narrative. The three sections into which the text is divided are not arranged in linear order, and some chapters are separated by pages containing only photographs with no captions to distract from the images. This means that the book need not be read in order, from beginning to end. One may dip into and out of it, perhaps re-reading sections or lingering over passages, seeing them in a new light after reading another part of the book.

Writing on Water should also be read with its context in mind. The type of Jewish community that the interviewees describe in childhood memories is highly similar to idealized modern imagined pasts, when prayer and its melodies were more "authentic," when people were brought up immersed in "correct" understandings of Jewish ritual, texts, and ways of living, and when people understood in their bones how to be Jewish, an imagined circumstance that might bear a suspicious resemblance to a performance of Fiddler on the Roof. The sound of this kind of imagined "authentic" Jewish past, often connected to recordings of famous cantors from the 1920s and 1930s, including Yossele Rosenblatt, Adolf Katchko, and Moyshe Oysher, has been used to delegitimize other forms of Jewish music, especially the folk-rock-influenced sound ushered into the American synagogue by musicians such as Debbie Friedman and Jeff Klepper. Although it is highly popular with many congregants today, and for many, represents the Jewish sound of their childhoods at American Jewish summer camps, its detractors claim that contemporary Jewish liturgical music is insufficiently "Jewish," in compar- 
ison to their notions of a pre-war Eastern or Central European synagogue filled with men all praying diligently from the heart, led by a hazzan who knew how to embellish each word of the prayer with the correct nusach, or musical formula, delivered with gorgeous artistic flair and ornamentation.

In many ways, this is exactly the kind of sound that Frigyesi's interviewees talk to her about. It is the sound that they recall from their pre-war childhoods, it is the sound that they try to teach her how to achieve on her own, and it is the sound that they struggle to maintain in the small, secret prayer houses where Frigyesi finds them. It is a sound world that really did exist. However, this sound is not the only "authentic" sound of Jewish prayer. Even Frigyesi's interviewees recall other styles of liturgical music that could be heard in their childhoods. The modernized Neolog synagogues in Budapest and Szeged and other cities employed organs and choirs, and indeed women's choirs, none of which were part of the sound world of the Orthodox prayer houses. These Neolog synagogues could be as welcoming and as well-attended as the Orthodox prayer houses, and several interviewees recalled timing their attendance at various synagogues at the High Holidays so as to be able to hear the best music that each tradition had to offer. And one of Frigyesi's interviewees, an organist at the Rabbinical Seminary in Budapest, observes that

As to tradition - the organ and choir have been part of the Jewish tradition for more than two hundred years! And this particular prayer house was originally built for services with an organ and a choir - it was designed with a special space on the balcony for the organ and the choir. To destroy this, to pretend that this two-hundred-year history never happened, to erase the differences among the different Jewish services... This new passion, a creed almost, that proclaims the existence of one single "correct" and "authentic" way of prayer and mold everything into a rigid homogenous mass like an army... It's sad, very sad! (p. 191)

While the sounds that Frigyesi describes are indeed authentically Jewish, and while her interviewees take pains to impress upon her that this is what they consider to be the true way of expressing prayer in sound, it is important to keep in mind that this is the authentic experience of this particular community. This kind of sounded prayer is authentic to a particular kind of Orthodox Judaism as practiced in Eastern and Central Europe in the nineteenth and twentieth centuries. Its authenticity is not devalued by the existence of other traditions that are authentic to other Jewish communities; similarly, it should not be used to undermine the authenticity of other Jewish expressions of sounded prayer. Writing on Water is a beautiful, poetic thick description of the sound and experience of prayer in a particular Jewish community in a particular time and place. This community is the product of a specific historical context, one that includes both the depredation of the Holocaust and decades of secrecy in a post-war Communist environment. 
Frigyesi does not set this context out explicitly; she hints at it, and expects her reader to pick up her clues and meet her halfway.

Because so much of the story is told so indirectly, this is not a book for beginning students of ethnography or of Jewish liturgical music. However, for the reader with enough experience to read between the lines and hear what Frigyesi and her interviewees do not say directly, this book will provide a deep, searching dive into the complexities at the heart of one of the most recognized Jewish liturgical traditions. Frigyesi's growth as an ethnographer plays out as a subtle background accompaniment to her exploration of the act of chanting prayer, and it will make this book a welcome treat to those readers who may not be ethnomusicologists but who might wonder what it is like to be one. The voices of Frigyesi's interviewees assume pride of place as the book progresses. It is a pleasure to meet them and to hear their memories both of prayer and of their lives in Hungary before the ravages of the Nazi and Communist eras. Because the book is so direct and so personal, much more so than the average scholarly monograph, it might also lend itself to the non-academic audience of a synagogue book group, where readers have the opportunity to discuss and explore their own reactions to this intriguing, multi-faceted work. 